\title{
Cost Management for Information and Communication Technology Projects
}

\author{
Zulkiflee Abdul-Samad ${ }^{1}$ and Patrick Pragasam Kulandaisamy ${ }^{2}$ \\ ${ }^{1}$ Senior Lecturer, Department of Quantity Surveying, Faculty of Built Environment, University of Malaya, 50603 Kuala \\ Lumpur, Malaysia. Email: zulkiflee1969@um.edu.my (corresponding author). \\ ${ }^{2}$ Project Manager, Ericsson Resource and Competence, Jalan Tiang U8/92, Bukit Jelutong Timor, 40150 Shah Alam, \\ Selangor, Malaysia, Email: patrick.pragasam@gmail.com
}

Project Management

Received October 9, 2021; revised December 7, 2021; January 2, 2022; accepted January 20, 2022

Available online February 12, 2022

\begin{abstract}
Information and communication technology (ICT) is an important sector that contributes to the development of a country. However, the success of this sector depends on the success of the ICT projects. Hence, ICT projects must be managed efficiently and effectively to ensure that they are successfully implemented. The literature review reveals that most of the ICT projects around the globe are in a challenged state, especially in terms of cost. This quantitative research aims to explore the cost influencing factors of the ICT projects in Malaysia and to build a cost influencing factors framework as a knowledge base for project managers. A 5-point Likert scale survey was conducted using the purposive sampling and the snowball sampling method to solicit responses from a large population of ICT project managers. The responses of 194 ICT project managers in Malaysia were analyzed, and the top 15 cost influencing factors were identified at different phases of a project. This result was used to build a cost influencing factors framework as a knowledge base for ICT project management.
\end{abstract}

Keywords: Project, cost management, cost overrun, information and communication technology (ICT).

Copyright $\odot$ Journal of Engineering, Project, and Production Management (EPPM-Journal).

DOI 10.32738/JEPPM-2022-0015

\section{Introduction}

Information and communication technology (ICT) is an emerging sector in Malaysia. Based on the study conducted by $\mathrm{Vu}$ et al. (2020) on 208 journals globally from the period of 1991 to 2018, it was revealed that the economic advancement of a country was positively correlated with the development of the ICT industry. ICT is the key driver for fostering positive market competition, increasing access to health and government services, and enhancing communication infrastructure (World Bank Annual Report, 2020). ICT spurred countries' economic development (Jin and Cho, 2015). The study of Seo et al. (2009) showed that labor productivity increased with the use of ICT, which contributed to the economic growth of a country. Various study data confirmed the positive relationship between ICT and GDP growth (Niebel, 2018). This was further strengthened by the study carried out by Appiah-Otto and Song (2021) on 123 countries that revealed the ICT sector had contributed positively to the economic development and growth of the country. Many countries have formulated an enhanced ICT policy to use and manage ICT technology effectively (Al-Mutawkkil et al., 2009). In Malaysia, ICT is an important sector that is a catalyst for sustainable economic development (Solarin et al., 2019).
However, a high percentage of ICT projects suffered from cost overruns (Procte and Businge, 2013). ICT projects were mostly constrained by the cost factor, which is one of the pillars of project success criteria (Catanio et al., 2013). This exploratory research explores the cost influencing factors of ICT projects in Malaysia and develops a cost influencing factors framework as a knowledge base for ICT project management internationally.

\subsection{Literature Review}

In this section, a literature review of referred journals and government department annual reports from the year 1990 till the year 2021 was conducted. This paper adopted a simplified systematic review method in which similar findings from journal papers were identified, analyzed, summarized, and grouped to form 15 major cost influencing factors for ICT projects, as shown in Table 1. The ICT industry is the backbone of national development. The benefits of ICT projects include cost savings, increased customer satisfaction, greater accountability, real-time monitoring of information, and operational efficiencies (Baltzan and Phillips, 2015; Siddique and Hussein, 2016). Increased ICT expenditure in Malaysia suggested that more and more local organizations integrated ICT into their business activities (Arokiasamy 
et al., 2015). Universities, smart houses, smart schools, and numerous research and development centers have also been built. The emphasis of all these initiatives was on improving the productivity of labor and resources. These were also aimed at improving ICT skills, technology and management capabilities towards increasing economic growth from an overall perspective.

\subsection{Knowledge Gap}

The most common reason for the failure of ICT projects in Malaysia was due to poor budget planning (Saleem et al., 2016). Inadequate knowledge of project management factors and project process factors also contributed to project failures. This lack of knowledge had been further researched (Nawi et al., 2011). ICT projects are unique and different from other projects in that they were subjected to failure due to the complexity of projects, uncertainty in the specifications, and lack of knowledge and expertise. These factors hindered the project managers from producing robust cost baselines and time schedules (Montequin et al., 2014). Analyzing and identifying factors that deviate from ICT projects, especially in terms of project cost, is an important knowledge base to bridge the gap that contributes to project cost overrun. ICT project cost overrun is an issue in Malaysia and abroad. Othman et al. (2009) presented the chaotic factors of ICT projects in Malaysia. Their study of experienced project managers who managed ICT megaprojects in Malaysia worth ranging from RM1.8 million to RM100 million pointed out that the ICT projects suffered from cost overrun problems.

\section{Method}

\subsection{Research Design}

This is an exploratory study where a deductive and quantitative approach was adopted. A well-structured methodology is essential to ensure that the right techniques are considered to sample and gather data most effectively and efficiently (Basias and Pollalis, 2018). A thorough literature review was done to understand the insights of the research area (Snyder, 2019). A research survey was designed to collect the data required for this study. The questionnaire consists of two sections, the first section is intended to gather information about the respondent and the second section is to explore the cost influencing factors for every phase of an ICT project. A 5-item Likert scale questionnaire was administrated through a nonprobability sampling technique. The purposive and snowball sampling techniques were utilized in this research study as this technique was deemed useful when the population size that intended to be studied is large (Etikan, 2016; Tongco, 2007). The survey was administrated to ICT project managers in Project Management Institute professional group and LinkedIn project management communities via an online survey platform, Survey Monkey, for six months from October 2020 to March 2021. year from. Using this method, wider coverage of the population of ICT project managers was possible to be reached out to (Serrador and Pinto, 2015). A pilot run was done, the survey questions were administrated to 30 participants and their feedback was received to further refine the survey questionnaire.

\subsection{Research Instrument and Statistical Method}

In this research, a statistical package for social science (SPSS) was used to analyze and produce output from the survey data. Cronbach Alpha test was used to measure the internal consistency and reliability of the questionnaire. The results obtained from the data were cross-checked using Table 1 as a reference to interpret the results. The relative importance index (RII) was done to rank the cost influencing factors based on their importance. The mean of the cost influencing factors was determined for every phase of the project. Based on the mean result, the top 3 cost influencing factors for each phase of the project were identified. A Mann-Whitney test was performed to determine the cost influencing factor mean ranking between the private and government sectors.

Table 1. Cronbach Alpha internal consistency range

\begin{tabular}{cc}
\hline Alpha Cronbach range & Strength of association \\
\hline$>0.90$ & Excellent \\
0.80 to $<0.9$ & Very good \\
0.70 to $<0.8$ & Good \\
0.60 to $<0,7$ & Moderate \\
Less than 0.6 & Poor \\
\hline
\end{tabular}

\section{Results and Discussion}

A total of 194 responses were received. All the participants are project managers who are managing ICT projects from various sectors.

\subsection{Demographics}

\subsubsection{Respondent age group}

The respondents to the survey in this research consist of participants from various age groups, as shown in Figure 1. In total, there were 194 respondents for this study. Ninetysix respondents were between the ages of 35 and 44, which is the majority age group in this study, which is $49.5 \%$ of the responses, followed by $33.0 \%$ of respondents who were between the ages of 45 and 54. There were also respondents from the retired project managers group who gave valuable insight experience in ICT project management. They were between the ages of 55 and 64 , which is $3.1 \%$, and older than 65 years old, which contributes to $1.0 \%$.

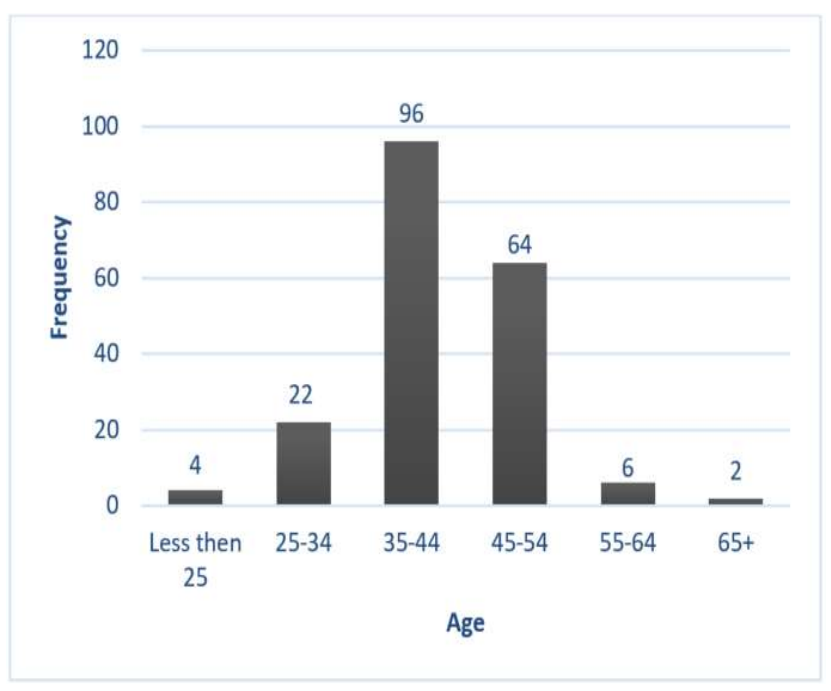

Fig. 1. Respondent age group

\subsubsection{Gender}


From the 194 respondents, 132 are male which is $68 \%$ of the total respondents, and 62 are female, which is $32 \%$ of the total respondents, as shown in Figure 2.

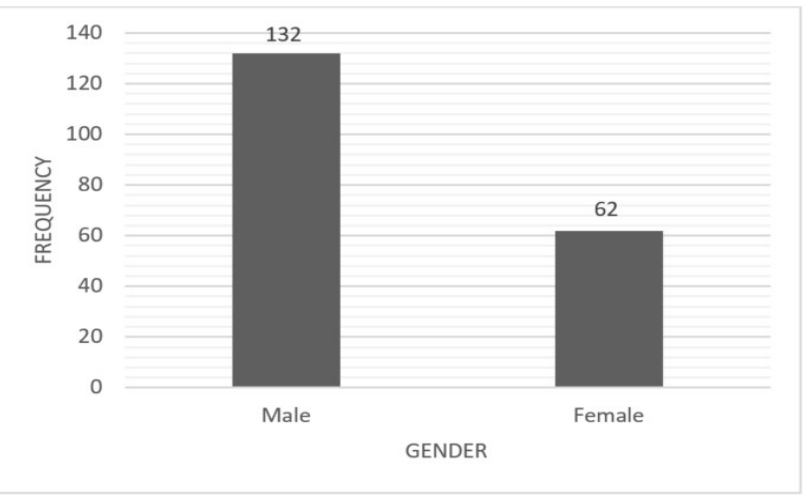

Fig. 2. Gender of the participants

\subsection{3. sector}

The participants are from various ICT sectors, as shown in Figure 3. The majority of the respondents are from the information technology sector, which consists of 86 respondents $(44.3 \%)$. The second-highest is from the telecommunication sector which consists of 32 respondents $(16.5 \%)$, and the third-highest is from the health care sector, which consists of 22 respondents $(11.3 \%)$. The remaining respondents are from other various sectors, as shown in Figure 3.
The experience of the participants handling ICT projects is determined in this section of the survey, as shown in Figure 4. The majority of the respondents are project managers who have experience in project management for more than 10 years. This is an advantage for this study from the aspect of the credibility and reliability of the data collected.

\subsection{Statistical Test Results}

\subsubsection{Reliability test}

The Cronbach Alpha test results were performed at every phase of the project, and the results are shown in Table 2.

\subsubsection{Relative importance index test}

The RII analysis was carried out on the cost influencing factors to rank order the cost influencing factors. Table 3 below is the results of the test.

Table 2. Cronbach Alpha test results

\begin{tabular}{ccc}
\hline Project phase & $\begin{array}{c}\text { Cronbach } \\
\text { Alpha }\end{array}$ & $\begin{array}{c}\text { Strength of } \\
\text { association }\end{array}$ \\
\hline $\begin{array}{c}\text { Preparation of request for } \\
\text { proposal (RFP) }\end{array}$ & 0.800 & Very Good \\
Initialization and planning & 0.873 & Very Good \\
Execution & 0.867 & Very Good \\
Monitoring and control & 0.787 & Good \\
Closing & 0.783 & Good \\
\hline
\end{tabular}

\subsubsection{Experience in handling ICT projects}

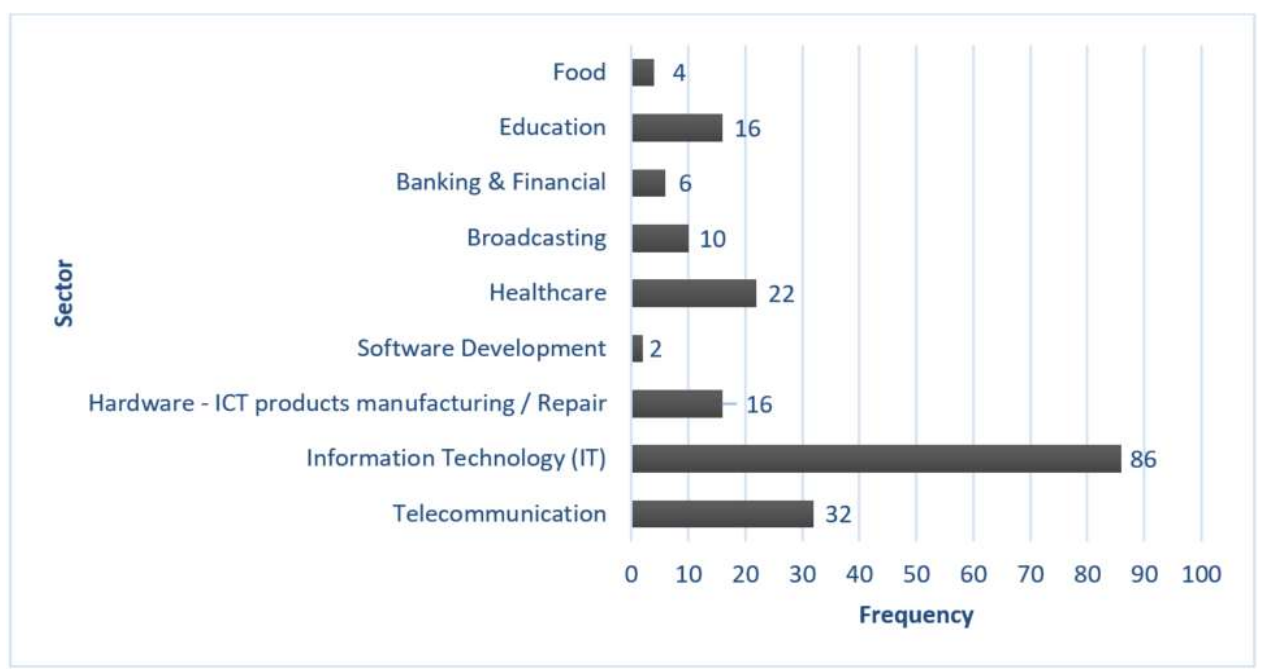

Fig. 3. ICT sectors

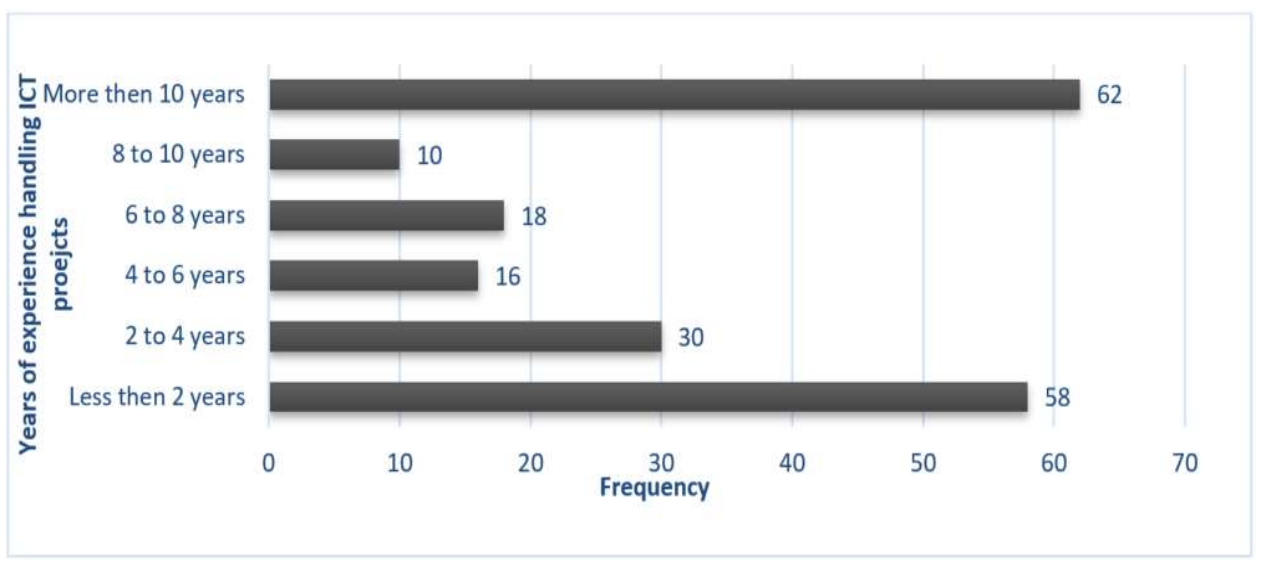

Fig. 4. Years of handling ICT projects

Journal of Engineering, Project, and Production Management, 2022, 12(2), 166-178 
Table 3. The ranking order of the cost influencing factor utilizing the RII

\begin{tabular}{|c|c|c|c|}
\hline Cost influencing factors & RII & Rank & Item mean \\
\hline Change request by the customer, management, or local authority & 0.802 & 1 & 4.01 \\
\hline Influence from top management & 0.798 & 2 & 3.99 \\
\hline High customer expectation & 0.773 & 3 & 3.866 \\
\hline Delay in material and parts & 0.771 & 4 & 3.856 \\
\hline Cost to rework due to quality defect & 0.767 & 5 & 3.835 \\
\hline Uncertainties in the project scope & 0.761 & 6 & 3.804 \\
\hline Poor project communication & 0.761 & 7 & 3.804 \\
\hline Short period for RFP reply & 0.757 & 8 & 3.784 \\
\hline Misinterpretation of the requirements & 0.753 & 9 & 3.763 \\
\hline Labor requirement underestimated & 0.753 & 10 & 3.763 \\
\hline Inadequate risk management plan & 0.753 & 11 & 3.763 \\
\hline Occurrence of untreated risk & 0.751 & 12 & 3.753 \\
\hline Scope creep & 0.746 & 13 & 3.732 \\
\hline Technical complexities & 0.744 & 14 & 3.722 \\
\hline Lack of experience in the project (new venture) & 0.742 & 15 & 3.711 \\
\hline Equipment cost underestimated & 0.742 & 16 & 3.711 \\
\hline Team competence - In-accurate cost data from the team & 0.74 & 17 & 3.701 \\
\hline Inability to detect problems early & 0.74 & 18 & 3.701 \\
\hline Unexpected failure or malfunction of the project deliverable & 0.738 & 19 & 3.691 \\
\hline Premature RFP documents & 0.736 & 20 & 3.68 \\
\hline Lack of understanding on the contract & 0.736 & 21 & 3.68 \\
\hline The penalty imposed by customers due to cost or schedule overrun & 0.734 & 22 & 3.67 \\
\hline Requirements for special toll/machinery missed out & 0.732 & 23 & 3.66 \\
\hline Improper resource management & 0.732 & 24 & 3.66 \\
\hline Lack of emphasis on the project quality & 0.732 & 25 & 3.66 \\
\hline Currency fluctuation & 0.732 & 26 & 3.66 \\
\hline Improper stakeholder Identification and engagement & 0.728 & 27 & 3.639 \\
\hline $\begin{array}{l}\text { Implementation of new law or regulation by the local authority } \\
\text { (compliance issue) }\end{array}$ & 0.724 & 28 & 3.619 \\
\hline Missed out on work package & 0.705 & 29 & 3.526 \\
\hline Wrong cost estimating method & 0.699 & 30 & 3.495 \\
\hline Political instability & 0.693 & 31 & 3.464 \\
\hline
\end{tabular}

\subsubsection{Measure of central tendency (mean)}

\subsubsection{Cost influencing factors during project RFP phase}

The seven cost influencing factors that have a significant effect during the project RFP phase of the ICT project cost management are shown in Table 4.

Table 4. Cost influencing factors during project RFP phase

\begin{tabular}{cc}
\hline Cost influencing factors & Mean \\
\hline Influence from top management & 3.9897 \\
Uncertainties in the project scope & 3.8041 \\
Short period for preparation of RFP reply & 3.7835 \\
Misinterpretation of the requirements & 3.7629 \\
Lack of experience in projects (new ventures) & 3.7113 \\
Team competence - In-accurate cost data & 3.701 \\
from the team & 3.6804 \\
Premature RFP documents (specifications, \\
\multicolumn{2}{c}{ contracts) } \\
\hline
\end{tabular}

From this research, it is found that the top 3 cost influencing factors on ICT projects in Malaysia during the RFP phase are influence from top management (3.99), uncertainties in project scope (3.80), and short time for preparation of an RFP reply (3.78).

The influence of top management has been identified as the major cost influencing factor during the RFP phase. Lack of senior management support leads the projects to failure (Abbasi et al., 2014). The main emphasis of the top management is on keeping the project budget as low as possible in the interest of increasing the chances of winning the contract (Dwivedi et al., 2013). This worsens if the top management lacks ICT knowledge, where they are not familiar with the target technologies of the ICT project and they tend to underestimate the budget (Nawi et al., 2012). Project managers, on the other hand, have to do their very best to satisfy the demands of the top management and finally end up with an unrealistic cost estimate (Ebad, 2018). This eventually leads to project cost overruns. The top management has to realize that keeping the budget low is 
important. However, the emphasis should also be on having a realistic and robust budget. This is important to ensure that the project can deliver the aimed objectives successfully within the determined budget (Soltani, 2020). Streamlining the budget is a risk and it is an act of skating on thin ice. If any risk were to emerge, the project would not be able to sustain the impact. Thus, it is important to have a buffer in the budget (Shash et al., 2021).

The second cost influencing factor is the uncertainties in project scope. Project scope is the foundation of the project management function that describes all the activities and components that have to be performed to deliver a product, service, or results (PMBOK, 2017). The scope of a project is a list of all the activities, resources consumed and the end-product results from a project (Cockfield, 1987). Project scope describes the boundaries of a project and is the basis for success criteria and the benefits the project should deliver (IPMA, 2015). One of the major contributors to project failure is a lack of understanding of the project scope in the initial phase of the project (Mirza et al., 2013). Frequent changes in the system development lead to poor scope management. The situation is worsened by the unrealistic expectations of the customers (Adam and Danaparamita, 2016). The project scope must be comprehensive, concise, clear, and unambiguous, and endorsed by project sponsors; it should be communicated to all stakeholders (Fenech and Raffaele, 2013). The success or failure of a project depends on how the project scope is managed (Fashina et al., 2020).

The third top cost influencing factor is the lead time for an RFP response. Short lead time for RFP response for ICT projects has always been a challenge to project managers. This usually happens due to the need to reply to multiple RFPs in parallel. Due to this, project managers find it always difficult to come up with a realistic and accurate budget. The time for RFP replies also depends on the complexity of the project. Complex projects require a longer lead time to come up with good and robust estimates. However, in reality, a short time to reply to an RFP leaves the project team in uncertainty (Chou et al., 2013). Responding to RFP's with a comprehensive and complete solution is one of the main importance in an ICT project (Rajbhoj et al., 2019).

\subsubsection{Cost influencing factors during project initialization and planning phase}

The 7 cost influencing factors that have a significant effect during the project initialization and planning phase of the ICT project cost management are shown in Table 5.

Table 5. Cost influencing factors during project initialization and planning phase

\begin{tabular}{cc}
\hline Cost Influencing Factors & Mean \\
\hline Labor requirement underestimated & 3.7629 \\
An inadequate risk management plan & 3.7629 \\
Equipment cost underestimated & 3.7113 \\
Requirement for special tool/machinery & 3.6598 \\
$\quad$ missed out & 3.6392 \\
Improper stakeholder identification and & \\
engagement (local authority, NGOs, etc.) & 3.5258 \\
Missed out on work package & 3.4948 \\
\hline Wrong cost estimating methods
\end{tabular}

From this research, it is found that the top 3 cost influencing factors of ICT projects in Malaysia during the project initialization and planning phases are an inadequate risk management plan (3.76), labor requirement underestimated (3.76) and equipment cost underestimated (3.71).

An inadequate risk management plan has been identified as the major cost influencing factor in the initialization and planning phase. Most project managers do perform a risk assessment and risk control but fail to come up with a proper risk management plan (Reed and Angolia, 2018). Despite continuous attention and emphasis on the positive contributions of risk management to a project, risk management practices are relatively lacking, and they have not been practiced holistically in the Malaysian ICT sector (Baharuddin and Yusof, 2018). One of the key factors that contribute to the inefficient management of risk in ICT projects in Malaysia is due the culture of the organization itself. The commitment by top management addresses project risks but is very poor in embracing risk management practices during project implementation. The poor risk management awareness of each team member has been implicated in the inconsistent involvement of stakeholders. The availability of the risk management processes alone is not sufficient. They have to be executed as planned to involve all the stakeholders in a project. If any stakeholders are not aware of the risk management plan, then the plan will not work (Abdullah and Shukor, 2017).

The second cost influencing factor is the labor requirement underestimated. Project resource allocation is important in a project and risk analysis in this area should be incorporated in project management to ensure proper resource allocations are in place in a project (Huynh and Nguyen, 2020). Accurate estimation of resources is one of the crucial tasks that determine the success of a project (Kaushik et al., 2020). A survey done by Ebad (2018) on ICT project failure factors in emerging markets such as Malaysia reveals that lack of resources, inexperienced resources, and high resource turnover rate are the major factors in project failures. In the real world, studies show that resources are often assigned to more than one project, even the project manager itself would probably be handling more than one project at any given time (Terlizzi et al., 2016). In this scenario, multitasking is inevitable. The resources that can multitask are regarded highly by employers. However, studies reveal that multitasking reduces the throughput of the team's work and impacts the team's ability to predict delivery consistently (Anestis and Kleopatra, 2017; PMBOK, 2017). Multitasking slows the progress of the entire team because team members waste time in context switching.

The third cost influencing factor is the equipment cost underestimated. One of the major reasons that contribute to this factor is the complexity of a project. ICT projects generally have a high level of uncertainty at the beginning of the project. In this setting, the chances of underestimating the requirements of the equipment are high. The increasing complexity of projects is one of the reasons for project failure (Bosch-Rekveldt et al., 2018). Complexity in the ICT project can be in various areas, the uncertainty of the scope of the project or it can be the uncertainty of the product scope (Yugue and Maximiano, 2012). The novelty of the technology is another factor that 
contributes to the complexity of the project. This gap can be bridged if the project team is given proper training and to build their competence. The complexity of a project can be due to the new technology itself or it can be complex due to the involvement of too many parties (Nawi et al., 2012). ICT projects have varying sizes, types, and complexities; hence ICT projects have to be administered with a more flexible and adaptive project management approach. Project managers cannot apply traditional methods of project management because the project management efforts have to be aligned with broader organizational expectations, one size does not fit all (Sheffield and Lemetayer, 2013).

\subsubsection{Cost influencing factors during the project execution phase}

The 7 cost influencing factors that have a significant effect during the project execution phase of the ICT project cost management are shown in Table 6.

Table 6. Cost influencing factors during project execution phase

\begin{tabular}{cc}
\hline Cost influencing factors & Mean \\
\hline Delay in material and parts & 3.8557 \\
Poor project communication & 3.8041 \\
Occurrence of untreated risk & 3.7526 \\
Scope creep & 3.732 \\
Technical complexities & 3.7216 \\
Improper resource management & 3.6598 \\
Lack of emphasis on project quality & 3.6598 \\
\hline
\end{tabular}

From this research, it is found that the top 3 cost influencing factors of ICT projects in Malaysia during the project execution phase are delays in materials and parts (weighted average of 3.86), poor project communication (weighted average of 3.80), and the occurrence of untreated risk (weighted average of 3.75).

Delays in materials and parts are inevitable in projects (Terzioglu et al., 2022). Some of the ICT projects involve the deployment of new technologies, thus the materials and parts required for the project are generally new in the market and limited vendors are available to supply these parts. Furthermore, these new parts are not readily available in the local market. The lead time for customs clearance is another reason to contribute to the overall materials and parts delivery time. Some of the materials and parts are dual-use parts, which are used for both commercial and by the military, these parts take longer approval and processing time to get clearance from customs. Oversized machinery which is unable to go through the airport scanners and into the airplane has to be delayed, be shipped by a special large plane, or be sent by ship via sea freight.

The second most cost influencing factor during the project execution phase is poor project communication. The ability to communicate at various levels in a project is a critical success factor in a project (Stevenson and Starkweather, 2017). Project communication is the central expectation of management in a project (IPMA, 2015). A project without effective project communication is doomed to fail (Mnkandla, 2013). It has to be a bi-directional communication, which involves bottom-up and top-bottom communication, this is to ensure that an effective communication flow is established. A good project communication plan ensures smooth communication with project stakeholders. Project communication is also challenged when the project teams are geographically distributed around the globe. This is a common setting in an ICT project environment. Proper knowledge transfer through well-defined training is essential to increase collaboration among the virtually scattered team to improve work efficiency and productivity (Galli, 2018; 2020). The time differences would lead to reduced real-time synchronous communication opportunities and the participants have to use asynchronous communication tools such as e-mails and other non-real-time discussion channels (Al-Zaidi and Qureshi, 2017). Thus, it would be a challenge to manage and coordinate the team due to the delay in the transfer and receiving of a message or instruction (Alzoubi et al., 2016).

The third cost influencing factor is the occurrence of an untreated risk. Risk management in an ICT project is essential knowledge that maximizes the performance of an ICT project in terms of finance and productivity, and it plays an important role in the project's success (Kinyua et al., 2015). Efficient project risk management in ICT projects positively correlates with projecting progress and project success (Alkhlaifat et al., 2021; Sandsto and RemeNess, 2021). Risk management is an iterative process, and it occurs throughout the project lifecycle (Kumarnayak and Mohanty, 2012).

Although risk management is important in a project, yet a very low proportion of risk management is practiced in reality (Teklemariam and Mnkandla, 2017). Based on Taherdoost and Keshavarzsaleh (2016), ICT projects are more vulnerable to risk due to their agility, high technology, and complex nature of projects. Studies done by Baharuddin and Yusof (2018) reveal that there is a lack of risk management emphasis in ICT projects, firstly due to the culture, where the risk management importance is not cascaded down effectively to the project team. This finding is consistent with the findings from other scholars, Altuntus et al. (2011).

\subsubsection{Cost influencing factors during project monitoring and control phase}

The five cost influencing factors that have a significant effect during the project monitoring and control phase of the ICT project cost management are shown in Table 7.

From this research, it is found that the top 3 cost influencing factors on ICT projects in Malaysia during the project monitoring and control phase are change requests by the customer, management or local authority (4.01), cost to rework due to quality defect (3.82), and inability to detect problems early (3.68).

Table 7. Cost influencing factors during project monitoring and control phase

\begin{tabular}{cc}
\hline Cost Influencing factor & Mean \\
\hline $\begin{array}{c}\text { Changes request by the customer, } \\
\text { management, or local authority }\end{array}$ & 4.0103 \\
$\begin{array}{c}\text { Cost to rework due to quality defect } \\
\text { Inability to detect problems early }\end{array}$ & 3.8351 \\
Currency fluctuation & 3.701 \\
Political instability & 3.6598 \\
\hline
\end{tabular}


The main cost influencing factor in the project monitoring and control phase is due to the change request by the customer, management, or the local authority. A change request is one of the biggest challenges in a project. A change request can be an issue as it can be a duplicated change request, frequent change request, or a poorly described change request (Cavalcanti et al., 2013). Poorly managed or uncontrolled changes can harm a project severely, including missed deadlines, budget overruns, and even project failure. However, managing the scope of the project diligently can reduce the need for change requests. The initial project scope has to be clearly defined and all changes during the lifecycle of the project are well managed (Abdilahi et al., 2020). As stated in PMBOK (2017), the later the change request emerges in a project lifecycle, the more it costs to implement the changes. This could lead the project to cost overrun and eventually to project failure. The adaptive approach, on the other hand, gives more flexibility to evolve and adapt to changes in a project (Butt and Jamal, 2017).

The second top cost influencing factor is the cost of rework due to quality defects. The cost of reworking, scraping, and claiming due to quality defects is a cost that is much higher than the appraisal cost that is required to detect a non-conformance of a deliverable through inspection or testing. This cost can escalate and lead to project cost overruns (Idrees and Shafiq, 2021). As stated in PMBOK, project quality management has to be incorporated in a project based on the organizational quality policy and it should govern all the activities performed in the project to ensure that the quality of a project deliverable is within its specification based on the customers' requirements and expectations (Beyene et al., 2018).

The third top cost influencing factor is the inability to detect problems early. The project manager has to ensure that close monitoring of the project is done to detect any deviation or sense any early warning signs of failure. Monitoring the project performance data regularly will give the project manager insight into the status of the upcoming deliverable (Egwunatum et al., 2021). The project manager also should refer to the lessons learned register as a knowledge base to understand the problems or failures that have emerged in past projects, so that the right focus can be given on the problem areas so that the potential problems can be rectified promptly (Dastyar et al., 2017).

\subsubsection{Cost influencing factors during project closure phase}

The five cost influencing factors that have a significant effect during the project closing phase of the ICT project cost management are shown in Table 8.

Table 8. Cost influencing factors during project closing phase

\begin{tabular}{cc}
\hline Cost influencing factor & Mean \\
\hline $\begin{array}{c}\text { High customer expectation } \\
\text { Unexpected failure or malfunction of the } \\
\text { project deliverable }\end{array}$ & 3.8247 \\
Lack of understanding on the contract & 3.6807 \\
The penalty imposed by customers due to & 3.6701 \\
$\begin{array}{c}\text { cost or schedule overrun } \\
\text { Implementation of new law or regulation by } \\
\text { the local authority (compliance issue) }\end{array}$ & 3.6186 \\
\hline
\end{tabular}

From this research, it is found that the top 3 cost influencing factors of ICT projects in Malaysia during the project closing phase are: high customer expectations (3.82), the unexpected failure of malfunction of the project deliverable (3.69), and lack of understanding of the contract (3.68).

The main cost influencing factor in the project closing phase is high customer expectations. It's always a challenge to project managers to deliver a project on time and within budget due to high customer expectations (Rivera and Kashiwagi, 2016). Customer expectation is an important factor that will determine customer satisfaction (Ali et al., 2015). Hence, it is important to fulfill customer expectations to ensure customer satisfaction and to achieve project success. Based on PMBOK (2017), customer expectations must be understood, evaluated, defined, and managed effectively to ensure customer satisfaction is achieved in a project. However, project managers have to be cautious as high customer expectations can lead to scope creep and finally lead the project to cost overruns (Komal et al., 2020). Thus, to avoid this problem, project managers have to manage customer expectations closely and diligently. Customer expectations have to be accomplished at every phase of the project or the sub-project, and have it had to be closed out formally with proper validation by the customer. The proposal for the next phase should be reviewed, agreed and documented before the start of the next phase (IPMA, 2015).

The second top cost influencing factor is the unexpected failure or malfunction of the project deliverable. ICT project deliverables involve high technology and innovation. At present, IT and infrastructure limitations are the barriers to successful ICT project implementation (Karunaratne et al., 2018). When companies choose to endeavor in projects to develop and implement new products, processes, and services, the reliability of the project's outcome becomes very uncertain (Mackelprang et al., 2015). PMBOK has emphasized that a product, process and service have to be thoroughly verified to ensure that they comply with the customer requirement specification and with the regulations. Project output performance has to be monitored and recorded. Project outputs are only to be released when they meet the quality criteria and are within the boundaries of performance tolerance (PMBOK, 2017).

The third cost influencing factor is the penalty imposed by customers due to cost or schedule overrun. Cost, schedule, and quality are the iron triangle of project management, or known as the triple constraint of a project (Pollack et al., 2018). Customer eye on these three parameters as the performance measure of a project. Hence, it's the responsibility of the project manager to ensure that these triple constraints are delivered per the contract agreed at the initial stage of the project (Patras and Banacu, 2016). However, for projects with a high level of uncertainties and subject to changes, the project manager has to consider time and material contracts rather than a fixed-price contract, as fixed-price contracts are more suitable for projects with known outcomes and may not be suitable for a project with a high level of uncertainties, such as in an ICT project (Jorgensen et al., 2017). Smart contracts are gaining momentum in the ICT projects where the contracts are in digital form. Contractual provisions are embedded in contractual software, performance is mediated by technological means and irrevocable as once the contract is initiated, it cannot be stopped or changed (Debono, 2019). 


\subsubsection{Mann-Whitney test}

To investigate the cost influencing factors in different organization settings, such as in the private sector and the government sector. A non-parametric Mann-Whitney U test was performed on the ordinal data obtained from two independent groups, which are the government sector respondent and the private sector respondent; 2-independent variable tests were done with an alpha value of $0.05(\alpha=$ 0.05 ). The null hypothesis assumes that the mean ranking of cost influencing factors in the private sector is equal to the mean ranking of the government sector. The null hypothesis is failed to be rejected when the $\mathrm{z}$-value is in the range of $1.975<\mathrm{z}<1.975$, meanwhile the null hypothesis is rejected when the value of $z>1.975$ or $z<-1.975$.

Null Hypothesis, $\mathrm{H}_{\mathrm{o}}=\mu_{\text {private }}=\mu_{\text {government }}$

Alternative Hypothesis, $\mathrm{H}_{\mathrm{a}}=\mu_{\text {private }} \neq \mu_{\text {government }}$

Table 9. Mann-Whitney test on the cost influencing factors (RFP phase)

\begin{tabular}{ccc}
\hline Label & Cost influencing factor & Z \\
\hline F8 & Missed out work package & -2.017 \\
F17 & Scope creep & -2.259 \\
F24 & Currency fluctuation & -2.334 \\
F26 & High customer expectation & -1.971 \\
F27 & Penalty imposed by customers & -2.038 \\
& due to cost or schedule overrun \\
F28 & Unexpected failure or malfunction & -2.276 \\
& of the project deliverable \\
\hline
\end{tabular}

From the Mann-Whitney test, it can be concluded that 6 out of 30 ICT projects' cost influencing factors are less significant in the government sector compared to the private sector. Missing out work packages is less significant in the government sector as there are various departments in the government department and they are set up in a project matrix. Therefore, every government department has a strong matrix organization, hence the team is focused on the projects based on their departments. They are the subject matter expert of the departmental activities and able to come up with work packages that are more comprehensive and complete, however in a private organization, there is no individual departmental project team, central project team which would need to run projects for various departments. Thus the area of coverage of the project is wider and the possibility to miss out work packages are more significant in the private sector. Scope creeps rarely occur in the government sector as they are the customers of their very own projects. Currency fluctuation doesn't impact government sectors as the ministry of finance absorbs the impact due to the fluctuation of currency. High customer expectations and penalties imposed by customers due to cost overrun or schedule overrun does not have a significant impact on a government department as the customer of the project is the government itself, and unexpected failure or malfunction of the project deliverable is linked to the shortage in time to reply RFQ. Hence the quality of the project is compromised to meet stringent baselines, which leads to unexpected failure of project deliverables. From the above statistical analysis, it is a significant finding that the cost influencing deviation between the government and private sector is $19.4 \%$, therefore it can be concluded that $80.6 \%$ of the cost influencing factors show a similarity between the government and private sector.

\subsection{Theoretical Contributions of the Study}

Over the years, the ICT project is getting more complex in terms of technology. The demand for the implantation of ICT projects is also rapidly increasing, thus introducing more constraints to project managers to keep up with the demands and complexity of the projects. Thus, project managers have to strategize the projects adequately to ensure the project is maneuvered within the cost and schedule baseline. A proper cost management methodology and techniques have to be adapted. This can only be done when a list of cost influencing factors is known upfront by the project managers and appropriate actions are taken to mitigate the factors. This study has revealed ICT project cost influencing factors at various stages of the project and their mitigation through a knowledge-based framework is presented

\subsection{Comparison of these Findings Against Previous Studies}

The influence of top management on the project has been studied by scholars globally. Based on the studies done by Busari et al. (2019), Adzmi and Hassan (2018), Ahimbisibwe et al. (2017), Yaghoobi (2018), Gingnell et al. (2014), Remus and Wiener (2009), and Gelbard and Carmeli (2009) have positively correlated the top management role to the project success, however, in this study, it has been revealed that the top management role is not necessarily correlated positively to the success of the project, it can also be negatively correlated to project success, which can lead to ICT project cost overrun. This is especially during the RFP stage, where unrealistic theoretical commitments are made as instructed by the top management to secure the project.

This study reveals that lead time to respond to RFQ has been a critical cost influencing factor of an ICT project. Various scholars globally have discussed project time management as a whole. Chiyangwa and Mnkandla (2017), Omar et al. (2016), Gingnell et al. (2014), Adzmi and Hassan (2018), and Yaghoobi (2018) showed the importance of managing the project time. However, less focus was given on time management before the project was awarded, which is the time for the preparation of the RFP response. In this study, it has been highlighted that the RFP response time is important to be analyzed. Top management needs to allocate a reasonably generous time to produce a robust and accurate RFQ response. But in actual context, time limitation has become a factor nowadays, as there are many ICT project RFQ's rolled out at a particular given time where the project manager and the project team are not given adequate time, but instead, they are required to process the RFPs within a short time and process multiple RFPs in parallel at any given time. Thus, the project managers and project team have to multitask and work in parallel to complete the RFQ response in a timely and accurate manner. Replying to RFQ's in a hurry leads to the introduction of errors and wrong estimates. The estimates are also influenced by the top management to desperately secure the contract. This wrong estimate leads to cost overruns when the project is being executed and finally leads to project failure.

Based on previous studies done by Guo (2019), Bhoola and Giangreco (2018), Daniel et al. (2018), Chiyangwa and Mnkandla (2017), and Engelbrecht et al. (2017), revealed that stakeholder relationship was an important factor in a project, however in this study, apart from stakeholder 
relationships, another area of concern in regard to stakeholders has been identified important. Stakeholder analysis before engaging in stakeholder relationships, the right stakeholders have to be identified in the first place. This is an important factor in ensuring that the project does not have new emerging stakeholders with different expectations and rules, which may interfere with the baseline set. This could lead to project costs and schedule overruns.

Scholars have done extensive studies on risk management, studies were done by Pimchangthong and Boonjing (2017) and Gingnell et al. (2014) have focused on the project risk internal and external. However, there is a lack of focus on the risk of currency fluctuations in the project. Currency fluctuation can lead to major cost issues within the project as the project cost baseline cannot be followed.

\subsection{Relevancy of Findings to the Global Context}

Based on the report published by the Standish Group, the cost overrun in the ICT project is still an unresolved issue. The Standish Group is an independent international IT research, known for its reports about information systems implementation projects in the public and private sectors. The Standish report (2020) reveals that $19 \%$ of ICT projects failed and $50 \%$ of ICT is in a challenged state globally. The study done by Ebad (2018) highlighted that the failure of ICT projects globally is still at a worrying stage. A study done by Soltani (2020) revealed that the ICT projects' performance issues still exist. This situation urges a need to study the cost influencing factors that cause the project to go into cost overrun. It is important to ensure that the emerging cost influencing factors are identified and addressed accordingly.

\subsection{Knowledge-based Framework}

A knowledge-based framework was established where the top 3 critical cost influencing factors for each phase of the project were listed. The summary of the knowledge-based framework is, as shown in Figure 5.

The top three cost influencing factors of ICT projects during the RFP phase are influenced from top management, Uncertainties in project scope, and short time for preparation of an RFP reply. The top 3 cost influencing factors of ICT projects during the Project Initialization and Planning phases are an inadequate risk management plan, Labor requirement underestimated and Equipment cost underestimated. The top 3 cost influencing factors of ICT projects during the project execution phase are Delay in materials and parts, Poor project communication, and the Occurrence of untreated risk. The top 3 cost influencing factors of ICT projects during the project monitoring and control phase are Change requests by the customer, management or local authority. Cost to rework due to quality defect and Inability to detect problems early. The top 3 influencing factors of ICT projects during the Project Closing phase are High customer expectation, unexpected failure of malfunction of the project deliverable, and lack of understanding of the contract.

\section{Conclusion}

This research has identified and ranked 31 cost influencing factors of ICT projects in Malaysia. The top 3 cost influencing factors for every phase of an ICT project were identified and a mitigation framework as a knowledge base has been proposed. This presents an overview of the findings while elaborating on the theoretical as well as the practical contribution of the study which will make the body of knowledge within the sphere of ICT project implementation in Malaysia. The research covers the study on cost influencing factors of ICT projects in Malaysia largely from the private sectors. All the major factors that influence the ICT project in terms of cost were analyzed and cross verified with the literature from various researchers from local and international. The difference of the cost influencing factors between the private sector and government sector was also analyzed to understand the significance of the cost influencing factors of these sectors. Recommendation for future potential research is to further study in ICT projects in government sectors. This is to understand the cost management constrain in the project with government settings, where the stakeholders involved have different power and influence level in projects where the environment and the culture of the project and project team may vary from the setting in private organizations. This will be an enrichment of the finding and in-depth knowledge complements of this research.

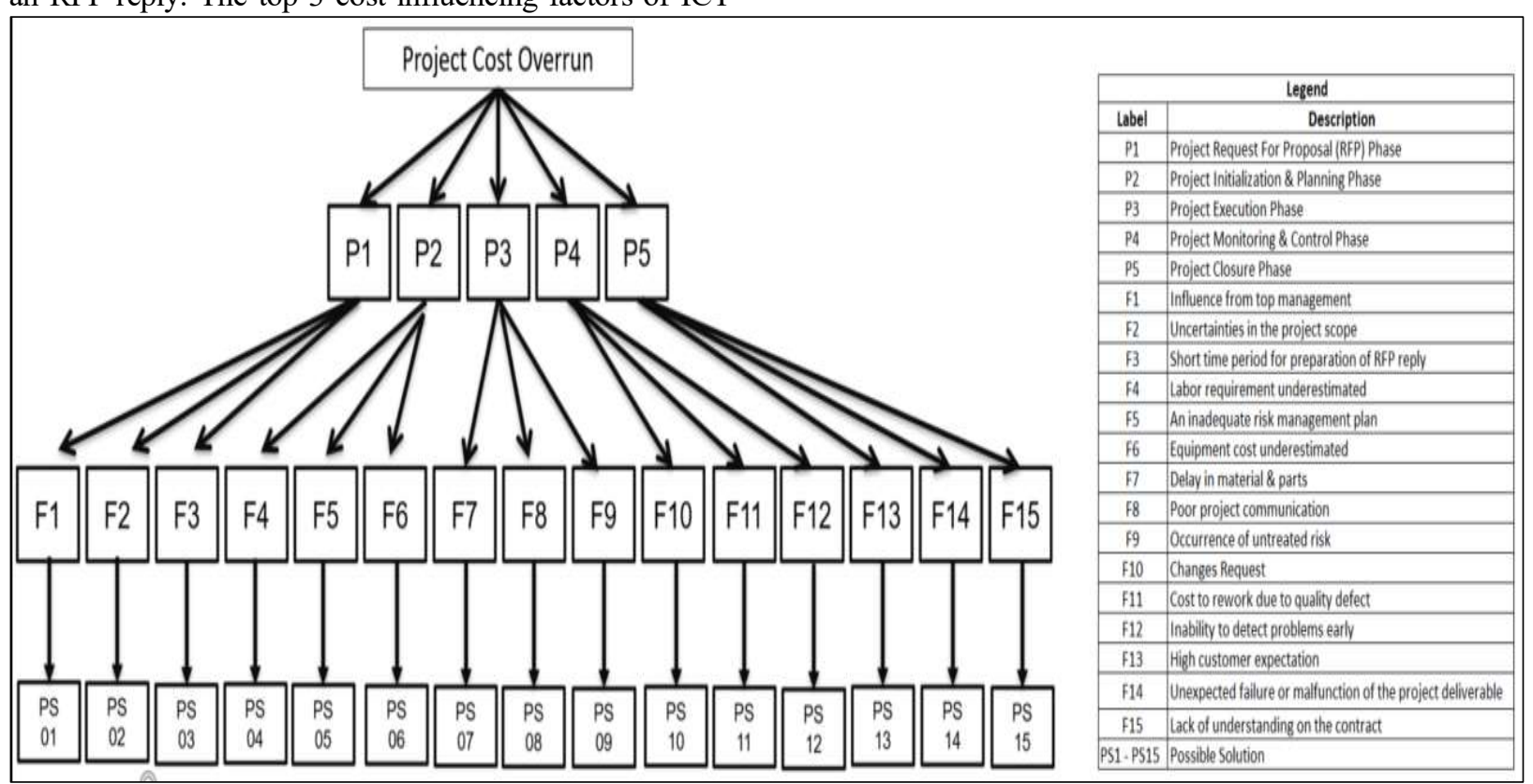

Fig 5. Cost Influencing factors knowledge base framework 


\section{References}

Abbasi, N., Wajid, I., Iqbal, Z., and Zafar, F. (2014). Project failure case studies and suggestion. International Journal of Computer Applications, 86(6), 34-39. Doi: 10.5120/14992-2696

Abdilahi, S.M., Fakunle, F. F., and Fashina, A.A. (2020). Exploring the extent to which project scope management processes influence the implementation of telecommunication projects. PM World Journal, 9(6), 177-185.

Abdullah, M., and Shukor, Z.A. (2017). The comparative moderating effect of risk management committee and audit committee on the association between voluntary risk management disclosure and firm performance. Jurnal Pengurusan, 51, 159-172. Doi: 10.17576/pengurusan-2017-51-14

Adam, A.R., and Danaparamita, M. (2016). Understanding the Influence of Poor Scope Management Affecting the Successful of an IT Project. International Conference on Information Management and Technology, Fiji, Japan, 124-129.

Adzmi, R.M., and Hassan, Z. (2018). A theoretical framework of critical success factors on information technology project management during project planning. International Journal of Engineering \& Technology. 7(4.35), Doi:10.14419/ijet.v7i4.35.23078

Ahimbisibwe, A., Daellenbach, U., and Cavana, R.Y. (2017). Empirical comparison of traditional plan-based and agile methodologies: Critical success factors for outsourced software development projects from vendors' perspective. Journal of Enterprise Information Management. 30(3), 400-453. Doi:10.1108/jeim-06-2015-0056

Alkhlaifat, B.I., Abdullah, A.A., and Al-Khamaiseh, Z.D. (2021). The effect of project management performance with the roles of project risk management: Evidence from ICT projects in public healthcare sectors in Jordan. International Journal of Academic Research in Business and Social Sciences, 11(3), 1278-1304. Doi: 10.6007/ijarbss/v11-i3/8869

Al-Mutawkkil, A., Heshmati, A., and Hwang, J. (2009). Development of telecommunication and broadcasting infrastructure indices at the global level. Telecommunications Policy, 33(3-4), 176-199. Doi: 10.1016/j.telpol.2008.12.008

Al-Zaidi, A., and Qureshi, R. (2017). Global Software Development Geographical Distance Communication Challenges. The International Arab Journal of Information Technology, 14(2), 215-222.

Ali, R., Leifu, G., Yasirrafiq, M., and Hassan, M. (2015). Role of perceived value, customer expectation, corporate image and perceived service quality on the customer satisfaction. Journal of Applied Business Research, 31(4), 1425-1436. Doi: 10.19030/jabr.v31i4.9328

Alzoubi, Y.I., Gill, A.Q., and Al-Ani, A. (2016). Empirical studies of geographically distributed agile development communication challenges: A systematic review. Information and Management, 53(1), 22-37. Doi: 10.1016/j.im.2015.08.003

Anestis, S., and Kleopatra, P. (2017). Exploring of the consequences of human resources multitasking in industrial automation projects: A tool to mitigate impacts. Procedia Engineering, 196, 738-745. doi: 10.1016/j.proeng.2017.08.002
Appiah-Otoo, I., and Song, N. (2021). The impact of ICT on economic growth-Comparing rich and poor countries. Telecommunications Policy, 45(2), 102082. Doi: 10.1016/j.telpol.2020.102082

Arokiasamy, A.R., Abdullah, A.G.K., and Ismail, A. (2015). Correlation between cultural perceptions, leadership style and ICT usage by school principals in Malaysia. Procedia - Social and Sciences,176(20), 319-332. Doi: 10.1016/j.sbspro.2015.01.478

Baharuddin, B., and Yusof, M.M. (2018). Evaluation of Risk management practices in information systems project in the public sector. Jurnal Pengurusan, 53, 2336. Doi:10.17576/pengurusan-2018-53-03

Baltzan, P., and Phillips, A. (2015). Business Driven Information systems. New York: McGraw-Hill/Irwin. 40-43.

Basias, N., and Pollalis, Y. (2018). Quantitative and qualitative research in business and technology: Justifying a suitable research methodology. Review of Integrative Business and Economics Research, 7 (1), 91-105.

Beyene, T.D., Gebeyehu, S.G., and Mengistu, A.T. (2018). Application of failure mode effect analysis (FMEA) to reduce downtime in a textile share company. Journal of Engineering, Project, and Production Management, 8(1), 40-46. Doi: 10.32738/JEPPM.201801.0005

Busari, A.H., Khan, S.N., Abdullah, S.M., and Mughal, Y.H. (2019). Transformational leadership style, followership, and factors of employees' reactions towards organizational change. Journal of Asia Business Studies. 14(2), 181-209. Doi:10.1108/jabs03-2018-0083

Butt, S.A., and Jamal, T. (2017). Frequent change request from user to handle cost on project in agile model. Asia Pacific Journal of Multidisciplinary Research, 5(2), 26-42.

Bosch-Rekveldt, M., Bakker, H., and Hertogh, M. (2018). Comparing project complexity across different industry sectors. Complexity, 2018, 1-15. Doi.org/10.1155/2018/3246508

Catanio, J. T., Armstrong, G., and Tucker, J. (2013). The effects of project management certification on the triple constraint. International Journal of Information Technology Project Management, 4(4), 93-111. Doi: 10.4018/ijitpm.2013100106

Cavalcanti, Y. C., Paulo Anselmo Da Mota Silveira Neto, Machado, I.D., Vale, T.F., Almeida, E.S., and Meira, S.R. (2013). Challenges and opportunities for software change request repositories: A systematic mapping study. Journal of Software: Evolution and Process, 26(7), 620-653. Doi: 10.1002/smr.1639

Chiyangwa, T.B., and Mnkandla, E. (2017). Modelling the critical success factors of agile software development projects in South Africa. South African Journal of Information Management, 19(1), 1-8.

Chou, J., Pham, A., and Wang, H. (2013). Bidding strategy to support decision-making by integrating fuzzy AHP and regression-based simulation, Automation in $\begin{array}{lrr}\text { Construction, } & 35, & 517-527 .\end{array}$ Doi:10.1016/j.autcon.2013.06.007

Cockfield, R.W. (1987). Scope Management. PM Network, 1(3), 12-15.

Dastyar, B., Kazemnejad, H., Sereshgi, A.A., and Jabalameli, M.A. (2017). Using data mining techniques to develop knowledge management in organizations: A review. Journal of Engineering, Project, and Production Management, 7(2), 80-89. Doi: 10.32738/JEPPM.201707.0004 
Debono, P. (2019). Transforming public procurement contracts into smart contracts. International Journal of Information Technology Project Management, 10(2), 16-28. Doi: 10.4018/ijitpm.2019040103

Dwivedi, Y.K., Ravichandran, K., Williams, M.D., Miller, S., Lal, B., Antony, G.V., and Kartik, M. (2013). IS/IT project failures: A review of the extant literature for deriving a taxonomy of failure factors. In International working conference on transfer and diffusion of IT, Springer, Berlin, Heidelberg, 73-88.

Ebad, S.A. (2018) An exploratory study of ICT projects failure in emerging markets. Journal of Global Information Technology Management,21(2), 139-160. Doi: 10.1080/1097198x.2018.1462071

Egwunatum, S.I., Awo-Osagie, A.I., Awodele, I.A., and Eze, E.C. (2021). Predicting cost performance of construction projects from projects procurement procedure. Journal of Engineering, Project, and Production Management, 11(3), 181-195. Doi: 10.2478/jeppm-2021-0018

Etikan, I. (2016). Comparison of convenience sampling and purposive sampling. American Journal of Theoretical and Applied Statistics, 5(1), 1-4. Doi:10.11648/j.ajtas.20160501.11

Fashina, A.A., Abdilahi, S.M., and Fakunle, F.F. (2020). Examining the challenges associated with the implementation of project scope management in telecommunication projects in Somaliland. PM World Journal, 9(3), 1-16.

Fenech, K., and De Raffaele, C. (2013). Overcoming ICT Project Failures-A Practical Perspective. World Congress on Computer and Information Technology, Institute of Electrical and Electronic Engineering. London, United Kingdom, 1-6.

Galli, B.J. (2020). How to effectively manage communication on project teams. IEEE Engineering Management Review, 48(1), 21-23. Doi: 10.1109/emr.2020.2971668

Galli, B.J. (2018). An evidence-based model of virtual team training and development. International Journal of Information Technology Project Management, 9(2), 65-79. Doi: 10.4018/ijitpm.2018040104

Gingnell, L., Franke, U., Lagerström, R., Ericsson, E., and Lilliesköld, J. (2014). Quantifying success factors for IT projects - an expert-based Bayesian model. Information systems management, 31(1), 21-36.

Idrees, S. and Shafiq, M.T. (2021). Factors for time and cost overrun in public projects. Journal of Engineering, Project, and Production Management, 11(3), 243-254. Doi: 10.2478/jeppm-2021-0023

IPMA (2015), IPMA Competence Baseline Version 4.0. Nijkerk, International Project Management Association, Netherlands, 40-45.

Huynh, Q.T., and Nguyen, N.T. (2020). Probabilistic method for managing common risks in software project scheduling based on program evaluation review technique. International Journal of Information Technology Project Management, 11(3), 77-94. Doi: 10.4018/ijitpm.2020070105

Jin, S., and Cho, C.M. (2015). Is ICT a new essential for national economic growth in an information society? Government Information Quarterly, 32(3), 253-260. Doi: 10.1016/j.giq.2015.04.007

Jorgensen, M., Mohagheghi, P., and Grimstad, S. (2017). Direct and indirect connections between type of contract and software project outcome. International
Journal of Project Management, 35(8), 1573-1586. Doi: 10.1016/j.ijproman.2017.09.003

Karunaratne, T., Peiris, C., and Hansson, H. (2018). Implementing small scale ICT projects in developing countries - How challenging is it? International Journal of Education and Development using Information and Communication Technology, 14(1), 118-140.

Kaushik, A., Tayal, D.K., and Yadav, K. (2020). The role of neural networks and metaheuristics in agile software development effort estimation. International Journal of Information Technology Project Management, 11(2), 50-71. Doi: 10.4018/ijitpm.2020040104

Kinyua, E., Ogollah, K., and Mburu, D.K. (2015). Effect of risk management strategies on project performance of small and medium information communication technology enterprises in Nairobi, Kenya. International Journal of Economics, Commerce and Management, 3(2), 1-30.

Kumarnayak, M., and Mohanty, D.S. (2012). Schedule risk analysis of ICT infrastructure projects. International Journal of Computer Applications, 38(5), 1-5. Doi: 10.5120/4601-6803

Komal, B., Janjua, U.I., Anwar, F., Madni, T.M., Cheema, M.F., Malik, M.N., and Shahid, A.R. (2020). The impact of scope creep on project success: An empirical investigation. IEEE Access, 8, 125755-125775. Doi:10.1109/access.2020.3007098

Mackelprang, A.W., Habermann, M., and Swink, M. (2015). How firm innovativeness and unexpected product reliability failures affect profitability. Journal of Operations Management, 38(1), 71-86. Doi: 10.1016/j.jom.2015.06.001

Mirza, M. N., Pourzolfaghar, Z., and Shahnazari, M. (2013). Significance of scope in project success. $\begin{array}{llll}\text { Procedia Technology, } & \text { 9, } & \text { 722-729. }\end{array}$ Doi:10.1016/j.protcy.2013.12.080

Mnkandla, E. (2013). A review of communication tools and techniques for successful ICT projects. The African Journal of Information Systems, 6(1),1.

Montequin, V., Cousillas, S., Ortega, F., and Villanueva, J. (2014). Analysis of the success factors and failure causes in information and communication technology (ICT) projects in Spain. Procedia Technology, 16, 992999. Doi:10.1016/j.protcy.2014.10.053

Nawi, H.S.A., Rahman, A.A., and Ibrahim, O. (2011). Government's ICT Project Failure Factors: A revisit. Proceedings of the International Conference on Research and Innovation in Information Systems. Institute of Electrical and Electronic Engineers, Kuala Lumpur Malaysia, 1-6

Niebel, T. (2018). ICT and economic growth - Comparing developing, emerging and developed countries. World Development, 104 , Doi:10.1016/j.worlddev.2017.11.024

Patras, M.V., and Banacu, C.S. (2016). Critical phases in the process of awarding public procurement contracts: a Romania case study. Journal of Engineering, Project, and Production Management, 6(2), 104-119. Doi: 10.32738/JEPPM.201607.0004

Pimchangthong, D., and Boonjing, V. (2017). Effects of risk management practices on IT project success. Management and production engineering review, 8.

Pollack, J., Helm, J., and Adler, D. (2018). What is the iron triangle, and how has it changed? International Journal of Managing Projects in Business, 11(2), 527-547. Doi: 10.1108/ijmpb-09-2017-0107 
Procte, C., and Businge, M. (2013). Involve users or fail: An IT project case study from east Africa. International Journal of Information Technology Project Management, 4(4), 51-65. Doi: 10.4018/ijitpm.2013100103

Othman, M., Hamdan, A.R., and Zain, A.M. (2009). A survey on chaotic disruption of ICT project management and planning: triggers, impact, challenges, and recommended measures. International Journal of Digital Content Technology and Its Applications, 3(1). Doi: 10.4156/jdcta.vol3.issue1.othman

Rajbhoj, A., Nistala, P., Kulkarni, V., and Ganesan, G. (2019). A RFP System for Generating Response to a Request for Proposal. Proceedings of the 12th Innovations on Software Engineering Conference, Pune, India, 1-9.

Reed, A.H., and Angolia, M. (2018). Risk management usage and impact on information systems project success. International Journal of Information Technology Project Management, 9(2), 1-19. Doi: 10.4018/ijitpm.2018040101

Rivera, A., and Kashiwagi, J. (2016). Identifying the state of the project management profession. Procedia Engineering, 145(7), 1386-1393. Doi: 10.1016/j.proeng.2016.04.204

Saleem, F., Salim, N., Altalhi, A.H., Abdullah, A.L., Ullah, Z., Baothman, F.A., and Junejo, M.H. (2016). Comparative study from several business cases and methodologies for ICT project evaluation. International Journal of Advanced Computer Science and Applications, 1(7), 420-427. Doi: 10.14569/ijacsa.2016.070654

Sandsto, R., and Reme-Ness, C. (2021). Agile practices and impacts on project success. Journal of Engineering, Project, and Production Management, 11(3), 255-262. Doi: 10.2478/jeppm-2021-0024

Seo, H., Lee, Y.S., and Oh, J.H. (2009). Does ICT investment widen the growth gap? Telecommunications Policy, 33(8), 422-431. Doi: 10.1016/j.telpol.2009.04.001

Serrador, P., and Pinto, J.K. (2015). Does Agile work? A quantitative analysis of agile project success. International Journal of Project Management, 33(5), 1040-1051. Doi: 10.1016/j.ijproman.2015.01.006

Shash, A.A., Al-Salti, M., Alshibani, A., and Hadidi, L. (2021). Predicting cost contingency using analytical hierarchy process and multi attribute utility theory. Journal of Engineering, Project, and Production Management, 11(3), 228-242. Doi: 10.2478/jeppm2021-0022

Sheffield, J., and Lemétayer, J. (2013). Factors associated with the software development agility of successful projects. International Journal of Project Management, 31(3), 459-472. Doi: 10.1016/j.ijproman.2012.09.011

Siddique, L., and Hussein, B.A. (2016). Grounded theory study of conflicts in Norwegian agile software projects: the project managers' perspective. Journal of Engineering, Project, and Production Management, 6(2), 120-135. Doi: 10.32738/JEPPM.201607.0005

Stevenson, D., and Starkweather, J.A. (2017). IT project success: The evaluation of 142 success factors by IT pm professionals. International Journal of Information Technology Project Management, 8(3), 1-21. Doi: 10.4018/ijitpm.2017070101

Snyder, H. (2019). Literature review as a research methodology: An overview and guidelines. Journal of
Business Research, 104(7), 333-339. Doi: 10.1016/j.jbusres.2019.07.039

Solarin, S.A., Shahbaz, M., Khan, H.N., and Razali, R.B. (2019). ICT, financial development, economic growth and electricity consumption: New evidence from Malaysia. Global Business Review, 1(22). Doi:10.1177/0972150918816899

Soltani, E. (2020). Business and project strategy alignment: ICT project success in Iran. Technology in Society, 63, 101404. Doi:10.1016/j.techsoc.2020.101404

Taherdoost, H., and Keshavarzsaleh, A. (2016). Critical factors that lead to projects' success/failure in global marketplace. Procedia Technology, 22, 1066-1075. Doi:10.1016/j.protcy.2016.01.151

Teklemariam, M.A., and Mnkandla, E. (2017). Software project risk management practice in Ethiopia. The Electronic Journal of Information Systems in Developing Countries, 79(1), 1-14. Doi: 10.1002/j.1681-4835.2017.tb00583.x

Terlizzi, M.A., de Souza Meirelles, F., and de Moraes, H.R.O.C. (2016). Barriers to the use of an IT project management methodology in a large financial institution. International Journal of Project Management, 34(3), 467-479. Doi: 10.1016/j.ijproman.2015.12.005

Terzioglu, T., Polat, G., and Turkoglu, H. (2022). Analysis of industrial formwork systems supply chain using value stream mapping. Journal of Engineering, Project, and Production Management, 12(1), 47-38. Doi: 10.32738/JEPPM-2022-0005

Tongco, M.D. (2007). Purposive sampling as a tool for informant selection. Ethnobotany Research and Applications, 5(3), 147-158. Doi: 10.17348/era.5.0.147-158

Vu, K., Hanafizadeh, P., and Bohlin, E. (2020). ICT as a driver of economic growth: A survey of the literature and directions for future research. Telecommunications, 44(2), 234-241. Doi: 10.1016/j.telpol.2020.101922

World Bank Annual Report. (2020). Supporting Countries in Unprecedented Times. Retrieved from https://openknowledge.worldbank.org/bitstream/handl e/10986/34406/9781464816192.pdf in 2020.

Yaghoobi, T. (2018). Prioritizing key success factors of software projects using fuzzy AHP. Journal of Software: Evolution and Process, 30(1), e1891.

Yugue, R.T., and Maximiano, A.C.A. (2012). Contribution to the research of project complexity and management processes. Proceedings of the IEEE International Conference on Management of Innovation and Technology Institute of Electrical and Electronic Engineers, Bali, Indonesia, 668673.

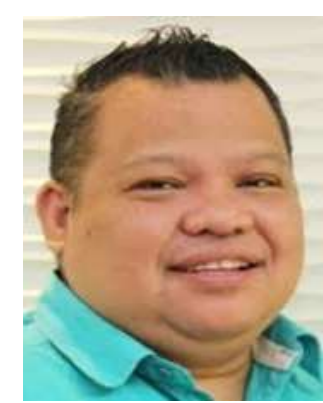

Zulkiflee Abdul-Samad is a senior lecturer in the Department of Quantity Surveying, Faculty of Built Environment, University of Malaya, Kuala Lumpur, Malaysia. He obtained his Ph.D. in Project Management from the University of Cambridge, England in 2008. His main interests include project management, construction management, construction business and entrepreneurship, construction economics, sustainability, and quantity surveying studies. He published articles in various high- 
impact academic journals such as the International Journal of Project Management, Building and Environment, Journal of Construction Engineering and Management, International Journal of Physical Sciences, Journal of Asian Architecture and Building Engineering, and Economic Research-Ekonomska Istraživanja. He also coauthored a book titled, "Sustainable Building through the Project Planning Process: The Case of Malaysia", published by the University of Malaya (UM) Press in 2017.

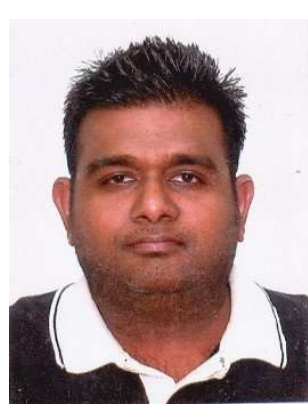

Patrick Pragasam Kulandaisamy is a project manager in information and communication technology (ICT) at Ericsson Resource and Competence in Shah Alam, Selangor, Malaysia. He holds a Bachelor of Electrical and Electronics Engineering (Hons) degree from Universiti Tenaga Nasional (UNITEN), Kajang, Selangor, Malaysia and a Master of Project Management degree from the University of Malaya, Kuala Lumpur, Malaysia. 